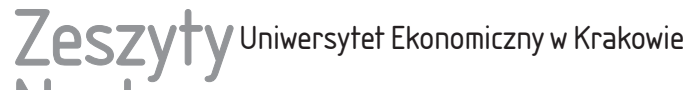 Naukowe
}

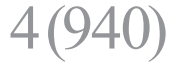

ISSN 1898-6447

Zesz. Nauk. UEK, 2015; 4(940): 145-161 DOI: 10.15678/ZNUEK.2015.0940.0411

\author{
Monika Miśkiewicz-Nawrocka \\ Katarzyna Zeug-Żebro \\ Katedra Matematyki \\ Uniwersytet Ekonomiczny w Katowicach
}

\section{Ocena stopnia zagrożenia bezrobociem województw Polski w latach 2005-2012}

\section{Streszczenie}

Zjawisko bezrobocia obserwuje się w sytuacji, w której ludność zdolna do pracy oraz deklarująca gotowość i chęć jej podjęcia nie znajduje zatrudnienia. Rosnący od 2009 r. poziom bezrobocia stanowi jeden z najbardziej istotnych i trudnych do rozwiązania problemów polskiej gospodarki. Wynika on między innymi z przekształceń gospodarczych, wzrastającego postępu techniczno-organizacyjnego w sferze produkcji, upadku całych gałęzi przemysłu, a także z braku odpowiednich kwalifikacji, braku doświadczenia zawodowego, niewielkiej mobilności ludności oraz wysokim kosztom dojazdu do pracy. Ze względu na długoterminowość tego zjawiska można obserwować negatywny wpływ na standard życia ludności, dynamikę rozwoju gospodarczego oraz nastroje społeczne.

Celem artykułu jest ocena zagrożenia bezrobociem województw Polski w latach 2005-2012. W badaniach wykorzystano dane pochodzące z Banku Danych Lokalnych GUS-u (www.stat.gov.pl).

Słowa kluczowe: miary taksonomiczne, stopa bezrobocia, klasyfikacja obiektów, analiza przestrzenna.

\section{Wprowadzenie}

Bezrobocie ze względu na swoje następstwa jest jednym z najtrudniejszych problemów społeczno-gospodarczych. Zjawisko bezrobocia obserwuje się 
w sytuacji, w którym ludność zdolna do pracy oraz deklarująca gotowość i chęć jej podjęcia nie znajduje zatrudnienia [Kwiatkowski 2002]. Rosnąca od 2009 r. wartość stopy bezrobocia w Polsce (rys. 1) stanowi trudny do rozwiązania problem polskiej gospodarki. Wynika on między innymi z przekształceń gospodarczych, wzrastającego postępu techniczno-organizacyjnego w sferze produkcji, upadku całych gałęzi przemysłu, a także z braku odpowiednich kwalifikacji i doświadczenia zawodowego, niewielkiej mobilności ludności oraz wysokich kosztów dojazdu do pracy [Dragan 2012]. Ze względu na długoterminowość tego zjawiska można obserwować negatywny wpływ na standard życia ludności, dynamikę rozwoju gospodarczego oraz nastroje społeczne.

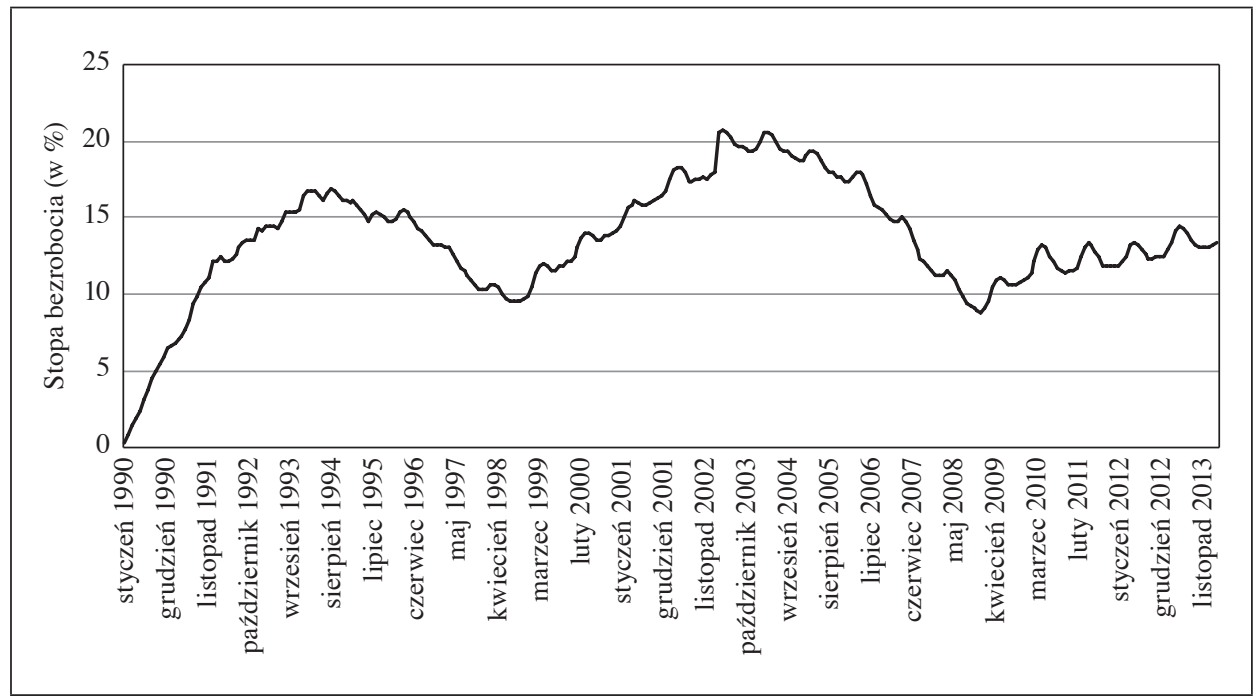

Objaśnienie: daty ujęte na rys. 1 są miesięcznymi wartościami stopy bezrobocia, które zostały wyznaczone automatycznie co 11 miesięcy za pomocą programu Excel.

Rys. 1. Miesięczne wartości stopy bezrobocia w Polsce w latach 1990-2013 Źródło: opracowanie własne.

Celem artykułu jest ocena stopnia zagrożenia bezrobociem województw Polski w latach 2005-2012 za pomocą wybranych miar taksonomicznych. W badaniach wykorzystano metody: miary rozwoju Z. Hellwiga [1968], miary syntetycznej D. Strahl [1978], absolutnego miernika rozwoju M. Cieślak [1974] oraz miary bezwzorcowej. W analizach uwzględniono dane pochodzące z Banku Danych Lokalnych GUS-u (www.stat.gov.pl). Wszystkie obliczenia i mapy wykonano w programie R oraz pakiecie Microsoft Excel. 


\section{Zmiany stopy bezrobocia w Polsce w latach 2005-2012}

W początkowych latach rozważanego okresu w wielu województwach Polski obserwowano spadek stopy bezrobocia. W szczególności w 2005 r. najniższą stopą bezrobocia (poniżej 15\%) charakteryzowały się województwa mazowieckie, małopolskie i wielkopolskie (rys. 2), zaś najwyższą (powyżej 25\%) zachodniopomorskie i warmińsko-mazurskie. W kolejnym roku do województw o najniższej wartości tego wskaźnika dołączyły województwa łódzkie, śląskie i podlaskie. W 2007 r. w prawie wszystkich województwach stopa bezrobocia była niższa niż 15\% (z wyjątkiem województw zachodniopomorskiego i warmińsko-mazurskiego), a w województwach mazowieckim, małopolskim, wielkopolskim i śląskim spadła do poziomu niższego niż 10\%. Wraz z kolejnym rokiem przybywa województw, w których wartość stopy bezrobocia należy do przedziału od 5-10\% (łódzkie, opolskie, podlaskie, pomorskie). Należy również zauważyć, że w 2008 r. we wszystkich województwach stopa bezrobocia uległa znacznemu obniżeniu. Od 2009 r. sytuacja na rynku pracy ulegała pogorszeniu i nie zmieniała się aż do 2012 r. Warto jednak podkreślić, że mimo ciągłego wzrostu bezrobocia, wartości jego wskaźnika w 2012 r. były niższe niż w 2005 r.

\section{Dobór cech diagnostycznych do oceny stopnia zagrożenia bezrobociem}

Przedmiotem badań była ocena stopnia zagrożenia bezrobociem wszystkich województw Polski w latach 2005-2012. Wyboru zmiennych pozwalających na tę ocenę dokonano tak, aby ostateczny zbiór cech pozwolił ustalić, które województwa należą do grupy o wysokim, średnim i niskim stadium zagrożenia tym zjawiskiem. W tabeli 1 przedstawiono zestaw cech diagnostycznych branych pod uwagę w badaniu, wyróżniając wśród nich stymulanty (S) i destymulanty (D). Podziału cech na stymulanty i destymulanty dokonano z wykorzystaniem współczynnika korelacji liniowej, obliczanym pomiędzy poszczególnymi zmiennymi a stopą bezrobocia. Wybrane zmienne diagnostyczne charakteryzują pewne grupy określające różne dziedziny życia społecznego, tj. stan ludności, rynek pracy, szkolnictwo wyższe, wynagrodzenia, wydatki budżetów województw, gospodarstwa domowe, migrację, łączność, produkcję sprzedaną i nakłady inwestycyjne. Dobór poniższych miar wynikał z analizy czynników determinujących poziom zagrożenia bezrobociem. 

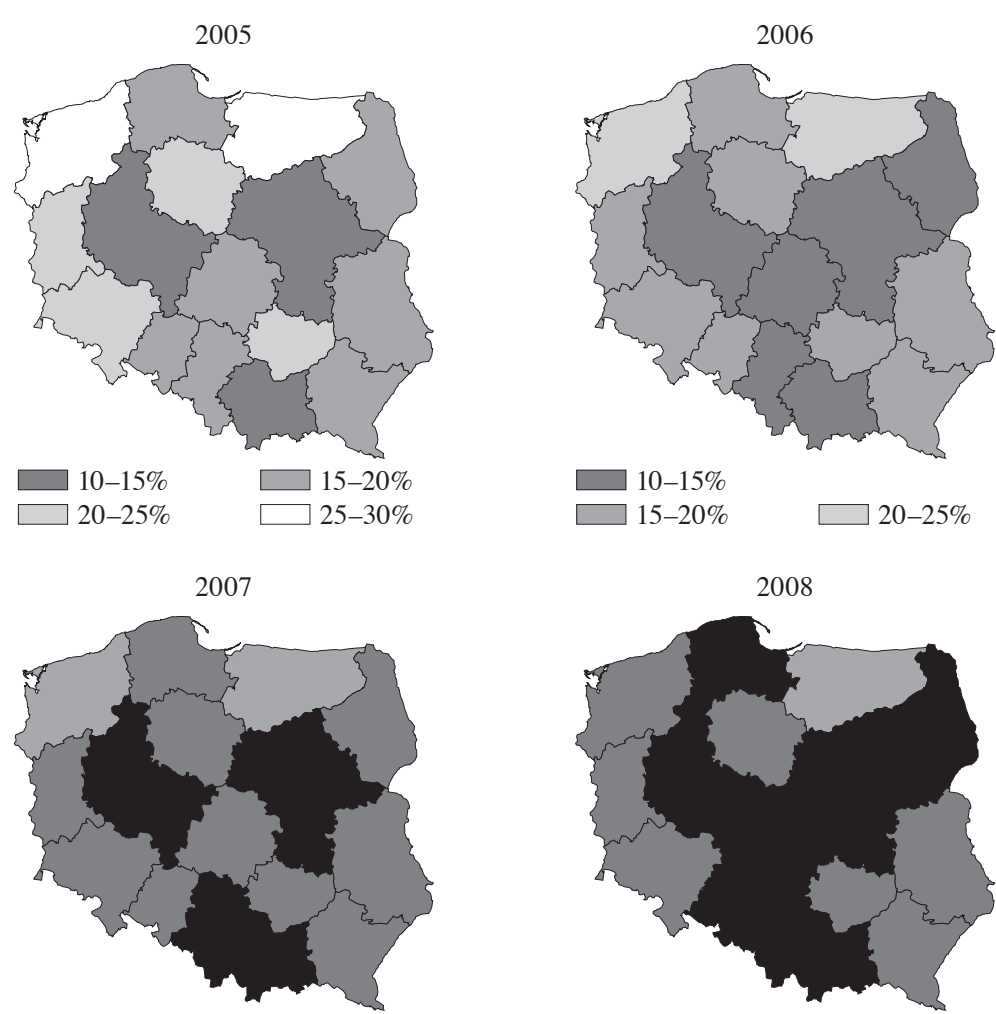

$5-10 \%$

$10-15 \%$

$15-20 \%$

$5-10 \%$

$10-15 \%$

$15-20 \%$
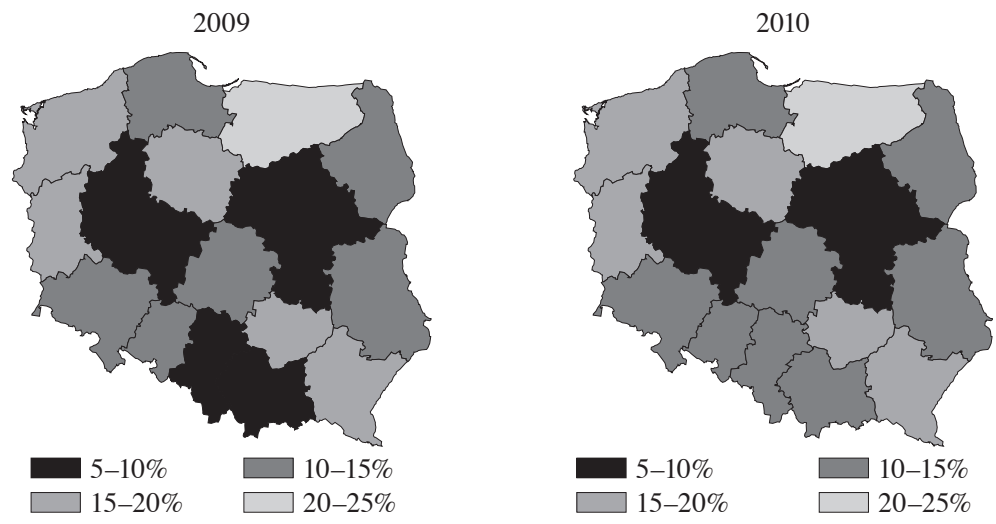


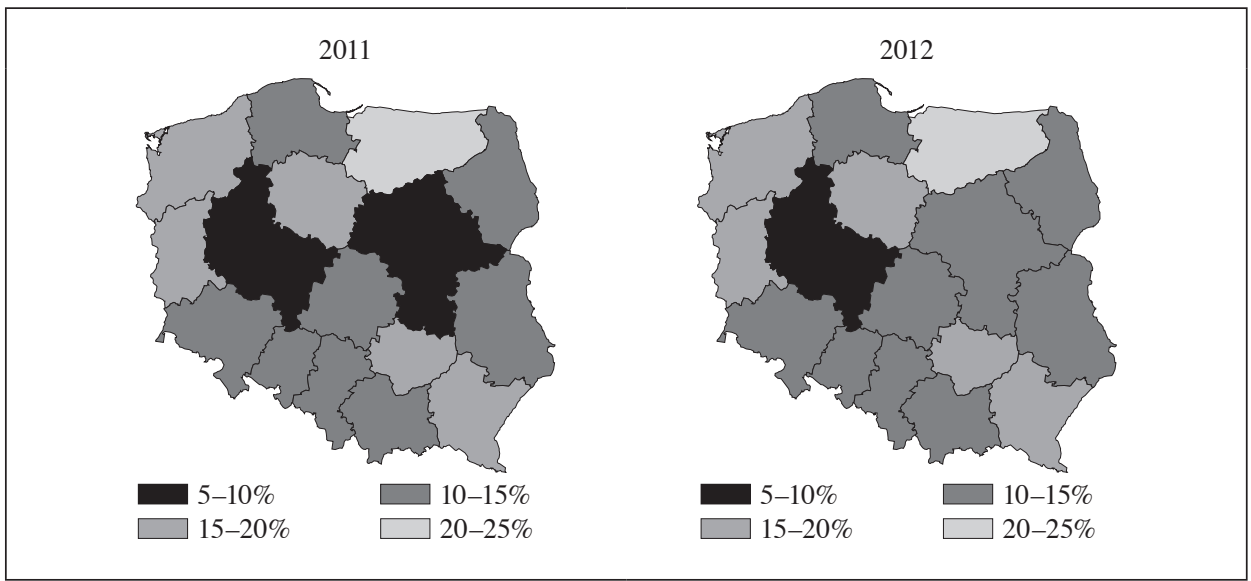

Rys. 2. Zmiany stopy bezrobocia w województwach Polski w latach 2005-2012 Źródło: opracowanie własne.

Tabela 1. Zestaw zmiennych diagnostycznych w badaniu stopnia zagrożenia bezrobociem województw Polski

\begin{tabular}{|c|l|c|}
\hline Symbol & \multicolumn{1}{|c|}{ Zmienna } & $\begin{array}{c}\text { Charakter } \\
\text { zmiennej }\end{array}$ \\
\hline X1 & Kobiety w wieku produkcyjnym (\%) & $\mathrm{S}$ \\
\hline X2 & Mężczyźni w wieku produkcyjnym (\%) & $\mathrm{S}$ \\
\hline X3 & Ludność na wsi w wieku produkcyjnym (\%) & $\mathrm{S}$ \\
\hline X4 & Ludność w mieście w wieku produkcyjnym (\%) & $\mathrm{S}$ \\
\hline X5 & Ludność aktywna zawodowo z wykształceniem wyższym (\%) & $\mathrm{D}$ \\
\hline X6 & $\begin{array}{l}\text { Ludność aktywna zawodowo z wykształceniem policealnym oraz śred- } \\
\text { nim zawodowym (\%) }\end{array}$ & $\mathrm{D}$ \\
\hline X7 & Ludność aktywna zawodowo z wykształceniem średnim ogólnym (\%) & $\mathrm{D}$ \\
\hline X8 & $\begin{array}{l}\text { Ludność aktywna zawodowo z wykształceniem zasadniczym zawodo- } \\
\text { wym (\%) }\end{array}$ & $\mathrm{D}$ \\
\hline X9 & $\begin{array}{l}\text { Ludność aktywna zawodowo z wykształceniem gimnazjalnym, podsta- } \\
\text { wowym i niższym (\%) }\end{array}$ & $\mathrm{S}$ \\
\hline X10 & Absolwenci szkół wyższych na 10 tys. ludności & $\mathrm{D}$ \\
\hline X11 & Przeciętne miesięczne wynagrodzenie brutto & $\mathrm{D}$ \\
\hline X12 & Przeciętne miesięczne wydatki na edukację & $\mathrm{D}$ \\
\hline X13 & Wydatki na oświatę i wychowanie & $\mathrm{D}$ \\
\hline X14 & $\begin{array}{l}\text { Wyposażenie w komputer osobisty z dostępem do Internetu w gospodar- } \\
\text { stwie domowym }\end{array}$ & $\mathrm{D}$ \\
\hline
\end{tabular}


cd. tabeli 1

\begin{tabular}{|c|c|c|}
\hline Symbol & Zmienna & $\begin{array}{l}\text { Charakter } \\
\text { zmiennej }\end{array}$ \\
\hline $\mathrm{X} 15$ & $\begin{array}{l}\text { Osoby w wieku 18-59 lat mieszkające w gospodarstwach domowych bez } \\
\text { osób pracujących (\%) }\end{array}$ & $\mathrm{S}$ \\
\hline $\mathrm{X} 16$ & Warunki pracy - zagrożenia związane ze środowiskiem pracy & $\mathrm{D}$ \\
\hline $\mathrm{X} 17$ & $\begin{array}{l}\text { Okres poszukiwania pracy/ bezrobotni długotrwale powyżej } 13 \text { miesięcy } \\
\text { - kobiety }\end{array}$ & $\mathrm{D}$ \\
\hline $\mathrm{X} 18$ & $\begin{array}{l}\text { Okres poszukiwania pracy/ bezrobotni długotrwale powyżej } 13 \text { miesięcy } \\
\text { - mężczyźni }\end{array}$ & $\mathrm{D}$ \\
\hline X19 & Wskaźnik zatrudnienia kobiet $\mathrm{w}$ wieku produkcyjnym (\%) & $\mathrm{D}$ \\
\hline $\mathrm{X} 20$ & Wskaźnik zatrudnienia mężczyzn w wieku produkcyjnym (\%) & $\mathrm{D}$ \\
\hline $\mathrm{X} 21$ & Wskaźnik zatrudnienia ludności z wykształceniem wyższym (\%) & $\mathrm{D}$ \\
\hline $\mathrm{X} 22$ & $\begin{array}{l}\text { Wskaźnik zatrudnienia ludności z wykształceniem policealnym oraz } \\
\text { średnim zawodowym }(\%)\end{array}$ & $\mathrm{D}$ \\
\hline $\mathrm{X} 23$ & Wskaźnik zatrudnienia ludności z wykształceniem średnim ogólnym (\%) & $\mathrm{D}$ \\
\hline $\mathrm{X} 24$ & $\begin{array}{l}\text { Wskaźnik zatrudnienia ludności z wykształceniem zasadniczym zawo- } \\
\text { dowym }(\%)\end{array}$ & $\mathrm{D}$ \\
\hline $\mathrm{X} 25$ & $\begin{array}{l}\text { Wskaźnik zatrudnienia ludności z wykształceniem gimnazjalnym, pod- } \\
\text { stawowym i niższym (\%) }\end{array}$ & $\mathrm{S}$ \\
\hline $\mathrm{X} 26$ & Wskaźnik zatrudnienia ludności w mieście (\%) & $\mathrm{D}$ \\
\hline $\mathrm{X} 27$ & Wskaźnik zatrudnienia ludności na wsi (\%) & $\mathrm{D}$ \\
\hline $\mathrm{X} 28$ & Współczynnik aktywności zawodowej kobiet w wieku produkcyjnym (\%) & $\mathrm{D}$ \\
\hline $\mathrm{X} 29$ & $\begin{array}{l}\text { Współczynnik aktywności zawodowej mężczyzn w wieku produkcyjnym } \\
(\%)\end{array}$ & $\mathrm{D}$ \\
\hline $\mathrm{X} 30$ & $\begin{array}{l}\text { Osoby dorosłe w wieku 25-64 lata uczestniczące w kształceniu i szkole- } \\
\text { niu (\%) }\end{array}$ & $\mathrm{D}$ \\
\hline $\mathrm{X} 31$ & $\begin{array}{l}\text { Produkcja sprzedana przemysłu na } 1 \text { mieszkańca (wskaźnik rozwoju } \\
\text { przemysłowego) }\end{array}$ & $\mathrm{D}$ \\
\hline $\mathrm{X} 32$ & $\begin{array}{l}\text { Saldo migracji wewnętrznych i zagranicznych na pobyt stały ludności } \\
\text { w wieku produkcyjnym (wskaźnik atrakcyjności regionu) }\end{array}$ & $\mathrm{D}$ \\
\hline $\mathrm{X} 33$ & $\begin{array}{l}\text { Długość dróg publicznych o twardej nawierzchni na } 100 \text { km² (w km) - } \\
\text { (wskaźnik rozwoju transportu) }\end{array}$ & $\mathrm{D}$ \\
\hline $\mathrm{X} 34$ & Nakłady inwestycyjne na 1 mieszkańca & $\mathrm{D}$ \\
\hline $\mathrm{X} 35$ & Gęstość zaludnienia na $1 \mathrm{~km}^{2}$ & $\mathrm{D}$ \\
\hline
\end{tabular}

Źródło: opracowanie własne.

Do dalszej analizy wybrano zmienne, dla których współczynnik zmienności $V_{z}>10 \%$. Dodatkowo, stosując metodę parametryczną Z. Hellwiga [1981], wyeliminowano zmienne silnie skorelowane z innymi cechami, tj. te zmienne, które są nośnikami podobnych informacji. Pozwoliło to wyłonić zmienne centralne oraz 
satelitarne. Ze względu na nieznaczne różnice występujące w zbiorach zmiennych centralnych w kolejnych latach jako zestaw finalny cech diagnostycznych rozpatrywany w latach 2005-2012 wybrano zmienne centralne wytypowane w 2012 r. W skład finalnego zbioru zmiennych diagnostycznych weszły: X6, X7, X8, X10, $\mathrm{X} 11, \mathrm{X} 15, \mathrm{X} 16, \mathrm{X} 17, \mathrm{X} 25$. Cechy te charakteryzują różne grupy, tj. X6, X7, X8 - stan ludności, X10 - szkolnictwo, X11 - wynagrodzenie, X15 - gospodarstwa domowe, X16, X17, X25 - rynek pracy.

\section{Wybrane miary taksonomiczne}

Głównym powodem szacowania miar taksonomicznych jest porządkowanie obiektów ze względu na poziom wielocechowego zjawiska. Różnice, jakie dostrzega się w konstrukcji tych miar, dotyczą głównie [Krakowiak-Bal 2005]: sposobu uwzględnienia cech stymulant (S) i destymulant (D), wyboru formuły normalizacyjnej, określenia wartości cech „wzorca”, budowy i własności miary.

Miara rozwoju Z. Hellwiga. Taksonomiczna miara rozwoju Z. Hellwiga [1968], jedna z najstarszych metod wzorcowych, wykorzystuje miary pozycyjne do porządkowania linowego obiektów. W pierwszym etapie konstruowania wzorca rozwoju przeprowadza się standaryzację cech diagnostycznych według formuły:

$$
z_{i j}=\frac{x_{i j}-\bar{x}_{j}}{s_{j}},
$$

a następnie wyznacza się współrzędne punktu $Z=\left(z_{01}, z_{02}, \ldots, z_{0 m}\right)$ zgodnie ze wzorem:

$$
z_{0 j}=\left\{\begin{array}{ll}
\max _{i} z_{i j} ; & j \in S \\
\min _{i} z_{i j} ; & j \in D
\end{array},\right.
$$

gdzie: $S$ oznacza zbiór stymulant, zaś $D$ destymulant. W kolejnym kroku oblicza się odległości euklidesowe pomiędzy między poszczególnymi obiektami a przyjętym punktem $Z$ :

$$
m_{i 0}=\left[\sum_{j=0}^{m}\left(z_{i j}-z_{0 j}\right)^{2}\right]^{0,5}, \quad i=1,2, \ldots, n .
$$

Obliczone wartości $m_{i 0}$ służą do obliczenia wartości syntetycznej miary rozwoju Hellwiga według wzoru:

$$
m_{i}=1-\frac{m_{i 0}}{m_{0}},
$$

gdzie:

$$
m_{0}=\frac{1}{n} \sum_{i=1}^{n} m_{i 0}+2\left[\frac{1}{n} \sum_{i=1}^{n}\left(m_{i 0}-\left(\frac{1}{n} \sum_{i=1}^{n} m_{i 0}\right)\right)^{2}\right]^{0,5} .
$$


Miara Hellwiga zwykle przyjmuje wartości z przedziału [0, 1]. Jednak w przypadku, gdy obiekt charakteryzowany jest wielkościami cech znacząco różniącymi się od wartości obiektu wzorcowego, może przyjąć wartości ujemne [Panek 2009]. Wyższe wartości tej miary oznaczają wyższy poziom rozwoju badanego obiektu.

Miara syntetyczna D. Strahl. Kolejnym zastosowanym w badaniach miernikiem taksonomicznym jest miara syntetyczna zaproponowana w 1978 r. przez D. Strahl [1978]. Jej wartości można obliczyć za pomocą następującego wzoru:

$$
m_{i}=\sum_{j=1}^{m} x_{i j}^{\prime}=\sum_{j=1}^{m_{1}} x_{i j}^{\prime S}+\sum_{j=1}^{m_{2}} x_{i j}^{\prime D},
$$

gdzie:

$$
\begin{aligned}
x_{i j}^{\prime S} & =\frac{x_{i j}}{\max _{i} x_{i j}}, \text { gdy } x_{i j} \text { jest wartością stymulnty, } \\
x_{i j}^{\prime D} & =\frac{\min _{i} x_{i j}}{x_{i j}}, \text { gdy } x_{i j} \text { jest wartością destymulnty. }
\end{aligned}
$$

Bezwzorcowa miara rozwoju. Bezwzorcową miarę syntetyczną szacuje się jako średnią arytmetyczną cech $x_{i j}^{\prime}$ :

$$
m_{i}=\frac{1}{n} \sum_{j=1}^{n} x_{i j}^{\prime}, \quad i=1,2, \ldots, n,
$$

gdzie $x_{i j}^{\prime}$ - wartością $j$-tej cechy po przeprowadzeniu unitaryzacji według wzoru:

$$
\begin{aligned}
x_{i j}^{\prime} & =\frac{x_{i j}-\min _{i} x_{i j}}{\max _{i} x_{i j}-\min _{i} x_{i j}}, \text { gdy } x_{i j} \text { jest wartością stymulnty, } \\
x_{i j}^{\prime} & =\frac{\max _{i} x_{i j}-x_{i j}}{\max _{i} x_{i j}-\min _{i} x_{i j}}, \text { gdy } x_{i j} \text { jest wartością destymulnty. }
\end{aligned}
$$

Absolutny miernik rozwoju według M. Cieślak. Absolutny miernik rozwoju [Cieślak 1974] jest miarą bezwzorcową wyrażoną wzorem:

$$
m_{i}=\sum_{j=1}^{m} x_{i j}^{\prime}
$$

gdzie $x_{i j}^{\prime}$ - unormowana wartość cechy według wzoru:

$$
\begin{gathered}
x_{i j}^{\prime}=\frac{x_{i j}}{s_{j}}, \text { gdy } x_{i j} \text { jest wartością stymulnty, } \\
x_{i j}^{\prime}=\frac{x_{i j}^{*}}{s_{j}^{*}}, \text { gdy } x_{i j} \text { jest wartością destymulnty, } \\
x_{i j}^{*}=\frac{1}{x_{i j}},
\end{gathered}
$$

$s_{j}$ - odchylenie standardowe $j$-tej cechy, $s_{j}^{*}$ - odchylenie standardowe $j^{*}$ tej cechy. 


\section{Analiza stopnia zagrożenia bezrobociem}

W celu uporządkowania wszystkich województw, ze względu na stopień zagrożenia bezrobociem, wykorzystano miarę rozwoju Z. Hellwiga, syntetyczną miarę rozwoju D. Strahl, miarę bezwzorcową oraz absolutny miernik rozwoju. Aby przeprowadzić analizę porównawczą stopnia zagrożenia bezrobociem w województwach Polski w latach 2005-2012, zmienne diagnostyczne poddano normalizacji stałymi w czasie parametrami normalizacyjnymi. Na rys. 3 przedstawiono graficzną ilustrację rankingów ustaloną na podstawie oszacowanych dla każdego województwa wartości wyżej wymienionych miar taksonomicznych w latach 2005-2012. Miejsce ze względu na miarę zostało przypisane zgodnie z zasadą: im większa wartość miernika, tym niższy numer w rankingu.

Analizując rezultaty porządkowania (rys. 3), można stwierdzić, że tylko województwo mazowieckie zajęło to samo miejsce (16.) pod względem wszystkich czterech miar w badanym okresie. Wyjątek stanowiły lata 2010 i 2011 (miara bezwzorcowa i miara rozwoju Z. Hellwiga). W latach 2005-2012 zdecydowanie najmniej zagrożone bezrobociem okazały się: województwo mazowieckie, a następnie województwa śląskie, łódzkie i dolnośląskie, natomiast najbardziej - województwa: warmińsko-mazurskie, zachodniopomorskie i podlaskie, które zajmowały miejsca $1-4$.

Przeprowadzone badania pozwoliły również na ocenę zmian w czasie wszystkich mierników. Pozytywne zmiany rozwoju zjawiska zagrożenia bezrobociem z wykorzystaniem miary Hellwiga zaobserwowano w województwach małopolskim i pomorskim. Dość wysoką dynamikę poziomu zagrożenia bezrobociem odnotowano również w województwach lubelskim, podlaskim, świętokrzyskim i opolskim. Województwa te polepszyły swoje pozycje w rankingu. Zdecydowanie pogorszyła się sytuacja rozwoju tego zjawiska w województwach zachodniopomorskim, dolnośląskim i lubelskim. Najbardziej stabilna sytuacja w tym zakresie wystąpiła w województwach: mazowieckim, śląskim, łódzkim, wielkopolskim i warmińsko-mazurskim. Województwa te albo w ogóle nie zmieniały miejsca w rankingu (z 2012 r. w porównaniu z 2005 r.), albo w latach 2006-2011 nieznacznie go polepszyły lub pogorszyły.

Poziom zagrożenia bezrobociem określany za pomocą miary Strahl w województwach: śląskim, lubuskim i łódzkim charakteryzował się nagłymi zmianami. W latach 2006-2010 obserwowano w tych województwach pogorszenie (śląskie) lub polepszenie (łódzkie i lubuskie) miejsca w rankingu w stosunku do 2005 r., po czym sytuacja w 2012 r. wracała do stanu początkowego (tj. do poziomu z 2005 r.) lub uległa poprawie. Nieznaczną zmianę na lepsze w rozwoju zjawiska zagrożenia bezrobociem odnotowano w województwach świętokrzyskim i opolskim, zaś pogorszenie sytuacji obserwowano w województwach zachodniopomorskim, 
dolnośląskim i kujawsko-pomorskim. W pozostałych województwach obserwowano stabilizację.

$\mathrm{Na}$ podstawie rankingu województw ze względu na stopień zagrożenia bezrobociem, stworzonego na podstawie absolutnego miernika rozwoju również można zaobserwować różnorodne zmiany w poszczególnych województwach. Największymi wahaniami poziomu zagrożenia bezrobociem w latach 2005-2012 charakteryzowały się województwa: lubuskie, zachodniopomorskie, opolskie, kujawsko-pomorskie, pomorskie i warmińsko-mazurskie. Najbardziej stabilną sytuacją w badanym okresie odnotowano w województwach: mazowieckim, małopolskim, lubelskim oraz podlaskim. W 2012 r. w województwach łódzkim, małopolskim, świętokrzyskim, opolskim i pomorskim zaobserwowano poprawę sytuacji w porównaniu z rankingiem z 2005 r., natomiast pogorszenie w badanym okresie odnotowano w województwach zachodniopomorskim, dolnośląskim, kujawsko-pomorskim i warmińsko-mazurskim.

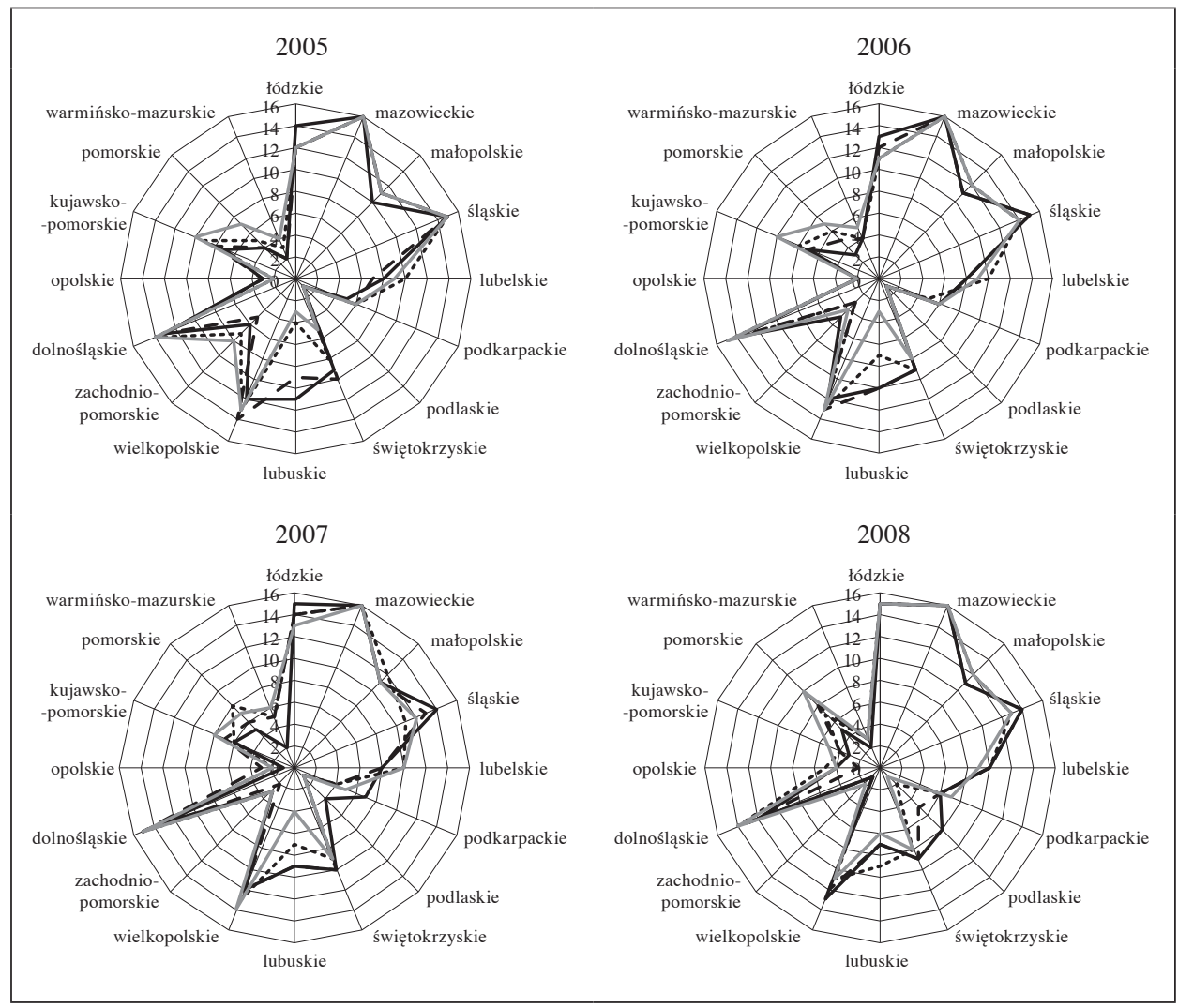




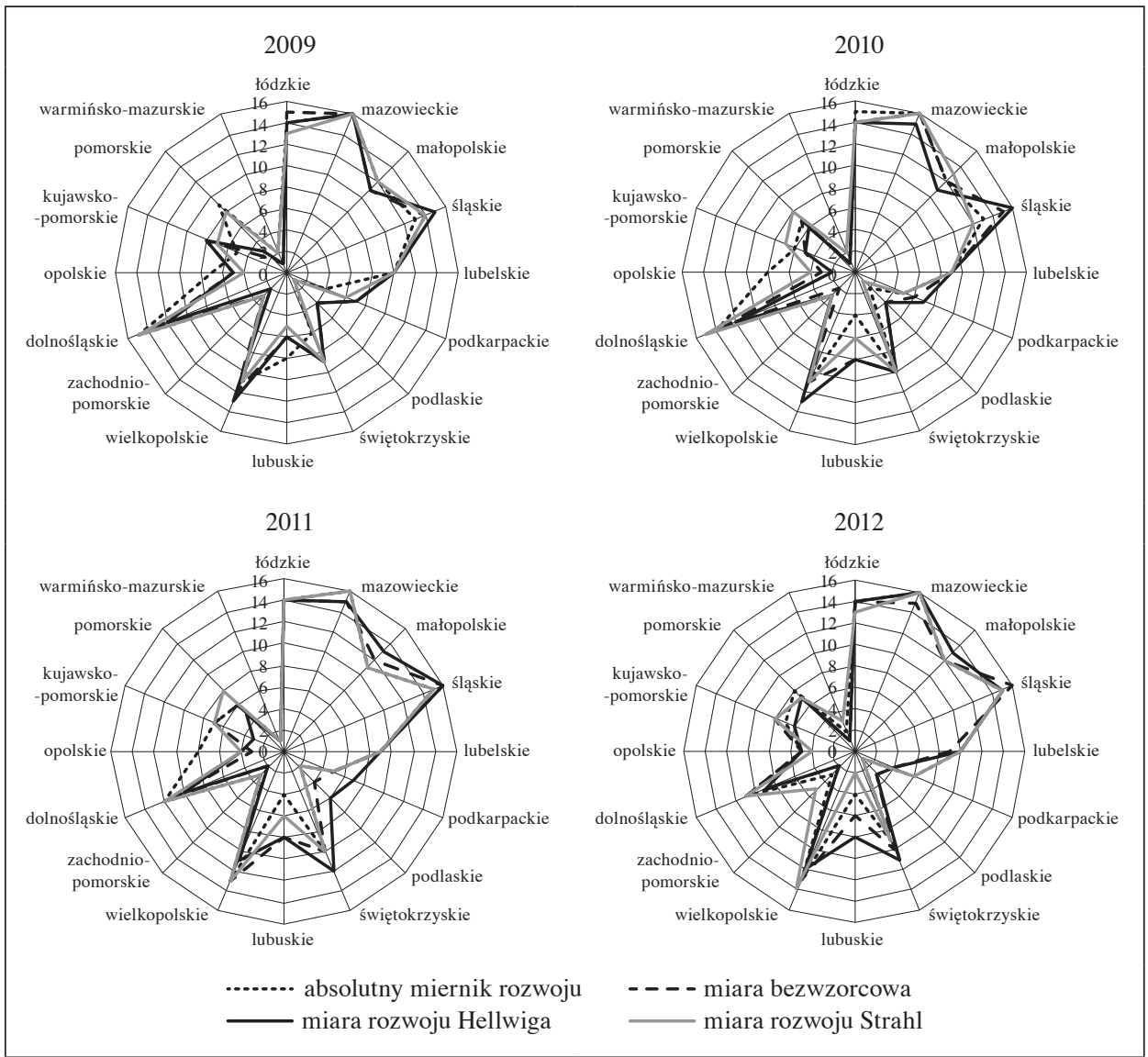

Rys. 3. Miejsca w rankingu województw według rozważanych miar taksonomicznych w latach 2005-2012

Źródło: opracowanie własne.

Analizując rankingi województw w latach 2005-2012, uzyskane za pomocą miary bezwzorcowej najbardziej stabilną sytuację za względu na poziom zagrożenia bezrobociem odnotowano w województwach: mazowieckim, małopolskim oraz świętokrzyskim. W pozostałych województwach obserwowano dużą dynamikę w poszczególnych latach badanego okresu. Pozytywne zmiany dotyczące zagrożenia bezrobociem można zauważyć w województwach: łódzkim, małopolskim, śląskim, lubelskim, podlaskim, opolskim oraz pomorskim. Najmniej korzystną sytuację można odnotować w województwach podkarpackim, lubuskim, zachodniopomorskim i dolnośląskim, dla których odnotowano pogorszenie miejsca w rankingu w 2012 r. w stosunku do 2005 r. 
Tabela 2. Wartości miary zgodności uporządkowania województw Polski w latach 2005-2012 wyznaczone za pomocą współczynnika korelacji rang Spearmanna

\begin{tabular}{|c|c|c|c|c|c|c|}
\hline & 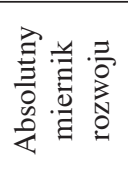 & 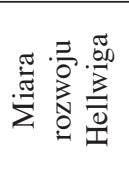 & 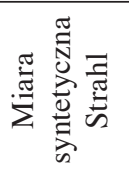 & 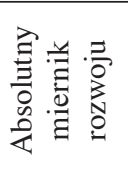 & 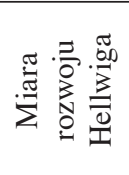 & 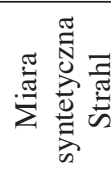 \\
\hline & \multicolumn{3}{|c|}{2005} & \multicolumn{3}{|c|}{2006} \\
\hline $\begin{array}{l}\text { Bezwzorcowa } \\
\text { miara rozwoju }\end{array}$ & 0,9250 & 0,9719 & 0,8531 & 0,9688 & 0,9844 & 0,8906 \\
\hline $\begin{array}{l}\text { Absolutny } \\
\text { miernik rozwoju }\end{array}$ & 1 & 0,8906 & 0,9719 & 1 & 0,9438 & 0,9594 \\
\hline \multirow[t]{2}{*}{$\begin{array}{l}\text { Miara rozwoju } \\
\text { Hellwiga }\end{array}$} & 0,8906 & 1 & 0,8188 & 0,9438 & 1 & 0,8656 \\
\hline & \multicolumn{3}{|c|}{2007} & \multicolumn{3}{|c|}{2008} \\
\hline $\begin{array}{l}\text { Bezwzorcowa } \\
\text { miara rozwoju }\end{array}$ & 0,9656 & 0,9375 & 0,9344 & 0,9563 & 0,9594 & 0,9469 \\
\hline $\begin{array}{l}\text { Absolutny } \\
\text { miernik rozwoju }\end{array}$ & 1 & 0,9031 & 0,9688 & 1 & 0,9094 & 0,9625 \\
\hline \multirow[t]{2}{*}{$\begin{array}{l}\text { Miara rozwoju } \\
\text { Hellwiga }\end{array}$} & 0,9031 & 1 & 0,8688 & 0,9094 & 1 & 0,8531 \\
\hline & \multicolumn{3}{|c|}{2009} & \multicolumn{3}{|c|}{2010} \\
\hline $\begin{array}{l}\text { Bezwzorcowa } \\
\text { miara rozwoju }\end{array}$ & 0,8406 & 0,9906 & 0,9063 & 0,9156 & 0,9813 & 0,9438 \\
\hline $\begin{array}{l}\text { Absolutny } \\
\text { miernik rozwoju }\end{array}$ & 1 & 0,8438 & 0,9406 & 1 & 0,8719 & 0,9563 \\
\hline \multirow[t]{2}{*}{$\begin{array}{l}\text { Miara rozwoju } \\
\text { Hellwiga }\end{array}$} & 0,8438 & 1 & 0,9125 & 0,8719 & 1 & 0,9000 \\
\hline & \multicolumn{3}{|c|}{2011} & \multicolumn{3}{|c|}{2012} \\
\hline $\begin{array}{l}\text { Bezwzorcowa } \\
\text { miara rozwoju }\end{array}$ & 0,9219 & 0,9438 & 0,9719 & 0,9688 & 0,9719 & 0,9313 \\
\hline $\begin{array}{l}\text { Absolutny } \\
\text { miernik rozwoju }\end{array}$ & 1 & 0,8625 & 0,9625 & 1 & 0,9406 & 0,9781 \\
\hline $\begin{array}{l}\text { Miara rozwoju } \\
\text { Hellwiga }\end{array}$ & 0,8625 & 1 & 0,8938 & 0,9406 & 1 & 0,8813 \\
\hline
\end{tabular}

Źródło: opracowanie własne.

W kolejnym kroku badań wyznaczono miarę zgodności uporządkowania województw Polski. W tym celu posłużono się współczynnikiem korelacji rang Spearmanna. Wyniki badania zależności pomiędzy pozycjami województw ze względu na stopień badanego zjawiska przedstawiono w tabeli 2. 
Wartości przedstawione w powyższej tabeli wskazują na silną korelację pomiędzy zajmowanymi miejscami województw oszacowanych wybranymi miarami w poszczególnych latach, oznacza to dużą zgodność uporządkowania województw ze względu na stopień zagrożenia bezrobociem według wybranych miar (81-100\%). Najwyższą zgodność uporządkowania województw we wszystkich latach można obserwować dla miejsc oszacowanych za pomocą bezwzorcowej miary rozwoju i miary Hellwiga (powyżej 93\% w każdym roku badanego okresu) oraz absolutnego miernika rozwoju i miary Sthral (powyżej 94\% w każdym roku badanego okresu).

Rezultaty uzyskane w wyniku porządkowania liniowego obiektów wybranymi miarami taksonomicznymi stanowiły podstawę klasyfikacji województw, ze względu na jednorodne grupy, z punktu widzenia osiągniętego stopnia badanego zjawiska (tj. zagrożenia bezrobociem). Całkowity przedział zmienności miar podzielono na cztery przedziały klasowe, do których przypisano poszczególne województwa, według następujących reguł:

I grupa (wysoki stopień zagrożenia bezrobociem): $\bar{m}+S_{m} \leq m_{i}$,

II grupa (średni stopień zagrożenia bezrobociem): $\bar{m} \leq m_{i}<\bar{m}+S_{m}$,

III grupa (niski stopień zagrożenia bezrobociem): $\bar{m}-S_{m} \leq m_{i}<\bar{m}$,

IV grupa (bardzo niski stopień zagrożenia bezrobociem): $m_{i}<\bar{m}-S_{m}$, gdzie: $\bar{m}=\frac{1}{n} \sum_{i=1}^{n} m_{i}, S_{m}=\sqrt{\frac{1}{n} \sum_{i=1}^{n}\left(m_{i}-\bar{m}\right)}$.

Za takim podejściem przemawiał głównie fakt, że ten sposób podziału jest w praktyce badawczej bardzo często stosowany [Kuc 2012; Taksonomiczna analiza... 2000]. Wyniki przestrzennego rozmieszczenia uzyskanych grup w latach 2005, 2008 i 2012 przedstawiono na rys. 4.

Klasyfikując województwa na grupy o różnym stopniu zaawansowania badanego zjawiska dla wybranych miar taksonomicznych można zauważyć, że najniższy poziom zagrożenia bezrobociem w rozpatrywanym przedziale czasowym występuje w województwach mazowieckim, śląskim i łódzkim, najwyższy zaś w województwach: podlaskim, warmińsko-mazurskim, zachodniopomorskim i opolskim. Województw wielkopolskie i podkarpackie w całym badanym okresie należały do tych samych przedziałów klasowych. Przypisanie do grup pozostałych województw zmieniało się w czasie i w zależności od przyjętej miary.

Porównując rezultaty uzyskane dla stopy bezrobocia w województwach Polski (rys. 2) z klasyfikacją tych województw według grup stopnia zagrożenia bezrobociem (rys. 4) w latach 2005 i 2008, można zauważyć pewne zbieżności przestrzennego rozmieszczenia najniższej i najwyższej stopy bezrobocia i klasy o niskim i wysokim stopniu zagrożenia bezrobociem. Dotyczyło to głównie województw: mazowieckiego i warmińsko-mazurskiego. W 2012 r. zbieżność tych wyników nie była już tak jednoznaczna. 


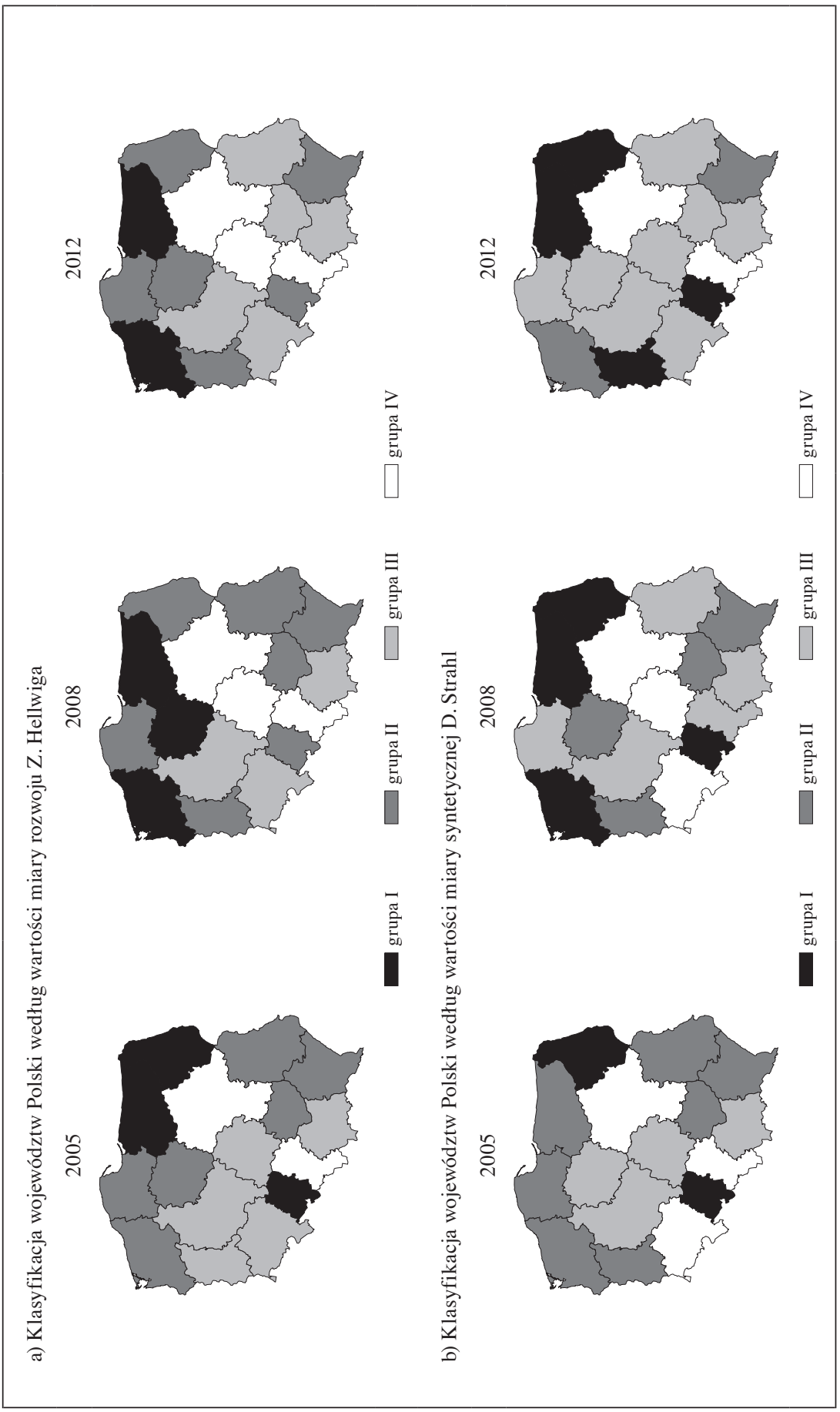




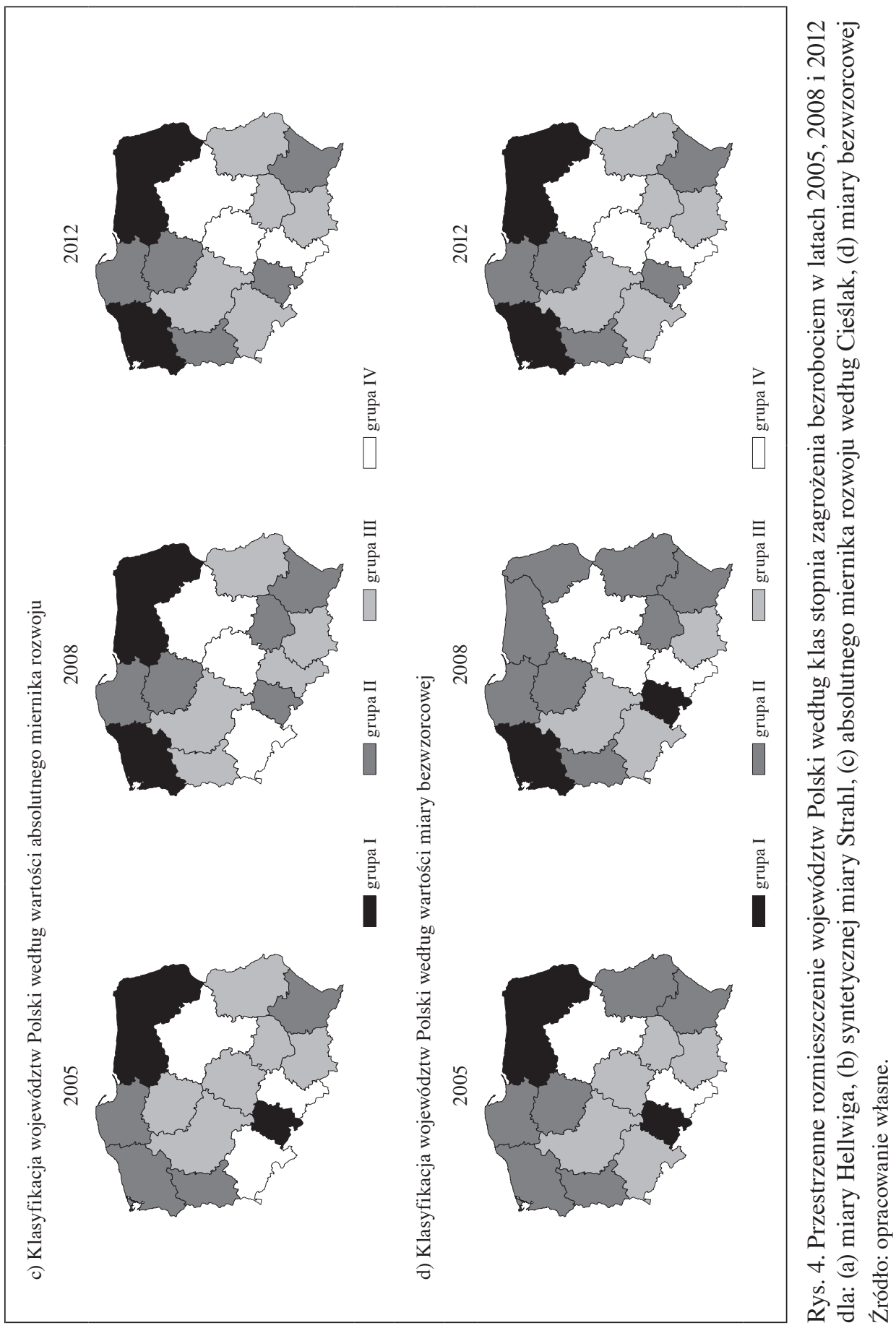




\section{Podsumowanie}

Celem artykułu była ocena stopnia zagrożenia bezrobociem województw Polski w latach 2005-2012. W badaniach posłużono się wybranymi miarami taksonomicznymi. Przeprowadzona analiza porównawcza województw jest istotna dla określenia dystansu dzielącego poszczególne województwa pod względem badanego zjawiska oraz do wyodrębnienia grup województw o zbliżonym stopniu zagrożenia bezrobociem.

Z przeprowadzonej analizy rozwoju tego zjawiska wynika, że w latach 20052012 zdecydowanie najniższym poziomem zagrożenia bezrobociem charakteryzowało się województwo mazowieckie, kolejnymi były województwa łódzkie, małopolskie i śląskie, natomiast najwyższe zagrożenie bezrobociem obserwowano w województwie zachodniopomorskim i warmińsko-mazurskim. Ponadto województwo mazowieckie zajęło to samo miejsce pod względem wszystkich czterech miar. Pozostałe województwa zmieniają miejsca w czasie i w zależności od przyjętej miary. Oznacza to, że porównywanie stopnia zagrożenia bezrobociem przez wybrane miary nie jest najlepszym rozwiązaniem.

Ogólnie można jednak twierdzić, że ze względu na ekonomiczno-społeczno-polityczne znaczenie zjawiska bezrobocia należy kontynuować tego typu badania. Można sądzić, że w przyszłości zróżnicowanie stopnia zagrożenia bezrobociem w poszczególnych województwch Polski będzie ulegało zmniejszeniu, natomiast nastąpi większe zróżnicowanie na poziomie powiatów. Warto zatem byłoby w kolejnych badaniach prowadzić analizy tego zjawiska w mniejszych jednostkach terytorialnych.

\section{Literatura}

Cieślak M. [1974], Taksonomiczna procedura prognozowania rozwoju gospodarczego i określenia potrzeb na kadry kwalifikowane, „Przegląd Statystyczny”, z. 1.

Dragan A. [2012], Programy walki z bezrobociem na poziomie Unii Europejskiej $i$ w wybranych państwach - Polsce, Finlandii, Irlandii i Niemczech, Kancelaria Senatu, Warszawa.

Hellwig Z. [1968], Zastosowanie metody taksonomicznej do typologicznego podziału krajów ze względu na poziom ich rozwoju i strukturę wykwalifikowanych kadr, ,Przegląd Statystyczny", nr 15(4).

Hellwig Z. [1981], Wielowymiarowa analiza porównawcza i jej zastosowanie w badaniach wielocechowych obiektów gospodarczych [w:] Metody i modele ekonomiczno-matematyczne $w$ doskonaleniu zarzqdzania gospodarkq socjalistycznq, red. W. Welfe, PWE, Warszawa.

Krakowiak-Bal A. [2005], Wykorzystanie wybranych miar syntetycznych do budowy miary rozwoju infrastruktury technicznej, „Infrastruktura i Ekologia Terenów Wiejskich", nr 3. 
Kwiatkowski E. [2002], Bezrobocie: podstawy teoretyczne, Wydawnictwo Naukowe PWN, Warszawa.

Kuc M. [2012], The Implementation of Synthetic Variable for Constructing the Standard of Living Measure in European Union Countries, Oeconomia Copernicana, nr 3, Polskie Towarzystwo Ekonomiczne Oddział w Toruniu.

Panek T. [2009], Statystyczne metody wielowymiarowej analizy porównawczej, Szkoła Główna Handlowa w Warszawie, Warszawa.

Strahl D. [1978], Propozycja konstrukcji miary syntetycznej, „Przegląd Statystyczny”, z. 2. Taksonomiczna analiza przestrzennego zróżnicowania poziomu życia w Polsce w ujęciu dynamicznym [2000], red. A. Zeliaś, Wydawnictwo Akademii Ekonomicznej w Krakowie, Kraków.

\section{Assessment of the Threat of Unemployment in Poland's Voivodships in the Years 2005-2012}

(Abstract)

Unemployment is observed when an individual is able to work and declares his or her readiness and willingness to take employment yet is not employed. Since 2008, rising unemployment has been one of the most important and difficult problems facing the Polish economy. On one hand, Poland's unemployment has stemmed from economic transformation, technical and organisational progress in the sphere of production, and the collapse of entire industries. On the other, the lack of qualifications and experience, low job mobility and high commuting costs are also to blame. Due to its long-term nature, it has adversely affected the Poland's standard of living, the dynamics of economic development and sentiments in society.

The main aim of this article is to assess the threat of unemployment Poland's voivodships faced in the years 2005-2012. The study employs a number of taxonomic measures and uses data from the Local Data Bank of the Central Statistical Office.

Keywords: taxonomic measures, unemployment rate, classification of objects, spatial analysis. 